\title{
Detection and Characterization of Xanthomonas vasicola pv. vasculorum (Cobb 1894) comb. nov. Causing Bacterial Leaf Streak of Corn in the United States
}

\author{
J. M. Lang, E. DuCharme, J. Ibarra Caballero, E. Luna, T. Hartman, M. Ortiz-Castro, K. Korus, J. Rascoe, \\ T. A. Jackson-Ziems, K. Broders, and J. E. Leach ${ }^{\dagger}$
}

First, second, third, fourth, sixth, tenth, and eleventh authors: Department of Bioagricultural Sciences and Pest Management, Colorado State University, Fort Collins, 80523-1177; fifth, seventh, and ninth authors: University of Nebraska-Lincoln, Lincoln 68583; seventh author: Alachua County Extension, University of Florida, Gainesville 32609; and eighth author: United States Department of Agriculture-Animal Plant Health Inspection Service-Plant Protection and Quarantine-CPHST, Beltsville, MD 20705.

Accepted for publication 29 June 2017.

\begin{abstract}
Bacterial leaf streak of corn (Zea mays) recently reached epidemic levels in three corn-growing states, and has been detected in another six states in the central United States. Xanthomonas vasicola was identified as the causal agent of this disease. A multilocus sequence alignment of six housekeeping genes and comparison of average nucleotide identity from draft genome sequence were used to confirm phylogenetic relationships and classification of this bacteria relative to other $X$. vasicola strains. $X$. vasicola isolates from Nebraska and South Africa were highly virulent

on corn and sugarcane and less virulent on sorghum but caused watersoaking symptoms that are typical of $X$. vasicola infection on the leaves of all three hosts. Based on host range and phylogenetic comparison, we propose the taxonomic designation of this organism to $X$. vasicola pv. vasculorum (Cobb 1894) comb. nov. Polymerase chain reaction-based diagnostic assays were developed that distinguish $X$. vasicola pv. vasculorum and X. vasicola $\mathrm{pv}$. holcicola from each other and from other Xanthomonas spp.
\end{abstract}

Corn (Zea mays) is a staple crop worldwide and is the most widely produced feed grain in the United States. In 2014, symptoms of bacterial leaf streak disease were first observed on corn in Nebraska and, by 2016, the disease was reported in Colorado, Iowa, Kansas, Minnesota, Oklahoma, South Dakota, and Texas (Korus et al. 2017). Given similarity of symptoms to those caused by other corn pathogens, it is not known how long the disease has been present in the United States. Bacterial leaf streak was first described in 1949 on corn in South Africa (Dyer 1949) but, prior to 2017, it had not been documented in the United States (Korus et al. 2017). Symptoms occur on leaves of field (dent) corn, sweet corn, seed corn, and popcorn crops, appearing as dark, water-soaked, linear lesions with wavy margins confined to the interveinal spaces. Due to the importance of corn in the United States, and the implications of the emergence and spread of a new disease, accurate identification of the causal agent and determination of its relationship to the strains from South Africa are of critical importance to the corn industry. Impacts on yield loss due to this disease are unknown.

The pathogen causing corn bacterial leaf streak was first named Xanthomonas campestris pv. vasculorum (Dye 1978) in Young et al. 1978, a species and pathovar that also included bacteria causing gumming disease of sugarcane and palm. In early reports, $X$. campestris pv. vasculorum strains isolated from sugarcane and palm were pathogenic on corn, sorghum, and sugarcane (Qhobela and Claflin 1992), whereas South African isolates from corn were virulent to corn only and not sorghum or sugarcane (Qhobela et al. 1990). The South African corn bacterial leaf streak isolates were further distinguished from $X$. campestris pv. holcicola (causal agent of sorghum bacterial

†Corresponding author: J. E. Leach; E-mail: jan.leach@colostate.edu

*The $\boldsymbol{e}$-Xtra logo stands for "electronic extra" and indicates that one supplementary table and four supplementary figures are published online.

(C) 2017 The American Phytopathological Society leaf streak) and sugarcane isolates of $X$. campestris pv. vasculorum by restriction fragment length polymorphism and, based on these differences, Qhobela et al. (1990) and Coutinho (1988) proposed renaming the corn isolates to $X$. campestris pv. zeae, to distinguish them from sugarcane $X$. campestris pv. vasculorum isolates and from $X$. campestris pv. holcicola. Later, based on DNA-DNA hybridization (Vauterin et al. 1995) and fatty acid profiling (Dookun et al. 2000), the species $X$. vasicola was proposed for $X$. campestris $\mathrm{pv}$. zeae, $X$. campestris $\mathrm{pv}$. vasculorum, and $X$. campestris pv. holcicola, with some sugarcane isolates being separated into a second species, $X$. axonopodis. More recent reports demonstrated that the corn bacterial leaf streak strain National Collection of Plant Pathogenic Bacteria (NCPPB) 206 caused disease on both corn and sugarcane (Karamura et al. 2015). This and other studies that included phylogeny based on multilocus sequence analyses (MLSA) proposed designation of the causal agents of gumming disease of sugarcane and bacterial leaf streak of corn as X. vasicola pv. vasculorum (Aritua et al. 2008; Coutinho et al. 2015; Dookun et al. 2000; Harrison and Studholme 2014; Karamura et al. 2015; Rademaker et al. 2005; Studholme et al. 2010; Vauterin et al. 1995; Wasukira et al. 2014). Although there is consensus among the reports, the pathovar naming was not proposed according to the rules of the International Society for Plant Pathology Committee on the Taxonomy of Plant-Pathogenic Bacteria International Standards for Naming Pathovars of Plant-Pathogenic Bacteria (Bull et al. 2008; Lapage et al. 1992). Thus, nomenclature of the $X$. vasicola strains that cause bacterial leaf streak of corn and gumming disease of sugarcane were still unresolved.

MLSA and whole-genome comparisons are now a regular accessory for classification of bacteria (Almeida et al. 2010; Jacques et al. 2016; Langlois et al. 2017; Young et al. 2008). Calculations of average nucleotide identity (ANI) from draft genomes are a widely accepted baseline for taxonomic placement of prokaryotes (Bull and Koike 2015). Although these tools are useful for placement of organisms into a common species (Konstantinidis and Tiedje 2005; Richter and Rosselló-Móra 2009), the assignment of plant pathogens as 
pathovars still requires determining an organism's capacity to cause disease on reciprocal hosts compared with pathotype strains of the various pathovars (Young et al. 2001). This is complicated if a pathogen can infect multiple hosts, as in the case of the $X$. vasicola complex.

In addition to resolving nomenclature, reliable and robust tools for accurate and rapid identification of the corn bacterial leaf streak pathogen were needed to confirm the presence of the pathogen, monitor its spread, and develop management practices. Polymerase chain reaction (PCR)-based diagnostic assays are available to identify $X$. vasicola to species level but these tests do not differentiate $X$. vasicola pv. vasculorum from $X$. vasicola pv. holcicola (Adriko et al. 2012; Lewis Ivey et al. 2010). Using the rich genome sequence data available for members of the genus Xanthomonas, unique sequences identified through comparative genomic approaches have enabled development of diagnostic assays for various Xanthomonas spp. and, in some cases, even pathovars (Ash et al. 2014; Lang et al. 2010, 2014; Langlois et al. 2017; Verdier et al. 2011). Thus, leveraging genomics is a powerful approach to developing diagnostic tools for the rapid and accurate disease diagnosis needed to inform disease mitigation strategies and regulatory entities.

In this study, we address the identity of the pathogen causing the newly found bacterial leaf streak of corn in the United States. We used MLSA and comparative genomic approaches to compare corn bacterial leaf streak isolates from the United States and South Africa to determine phylogenetic relationships to other Xanthomonas spp. and pathovars. We performed greenhouse inoculations of corn, sugarcane, and sorghum to determine host range of the U.S. strains. Based on this work, we propose the U.S. strains causing bacterial leaf streak of corn, formerly named $X$. campestris pv. vasculorum, $X$. campestris pv. zeae, or $X$. vasicola, be named $X$. vasicola $\mathrm{pv}$. vasculorum (Cobb 1894) comb. nov. (Cobb 1894). Finally, we developed primers for PCR-based diagnostic assays that distinguish the corn bacterial leaf streak pathogen $X$. vasicola $\mathrm{pv}$. vasculorum and the sorghum bacterial leaf streak pathogen $X$. vasicola $\mathrm{pv}$. holcicola from each other and from other Xanthomonas spp.

\section{MATERIALS AND METHODS}

MLSA. Bacterial strains (Table 1) were grown overnight at $28^{\circ} \mathrm{C}$ on nutrient agar (Becton, Dickinson and Company, Franklin Lakes, $\mathrm{NJ}$ ) to reduce production of extracellular polysaccharides that impact quality of DNA extractions. Genomic DNA for all strains in this study was prepared using the Easy DNA kit (Life Technologies, Grand Island, NY) according to the manufacturer's recommendations, except that the final product was recovered in $50 \mu \mathrm{l}$ of sterile, molecular-grade water. If public genome or partial sequence were not available (Tables 1 and 2), six genes ( $a t p D, d n a K, g y r B$, $f u s A$, lepA, and $r p o D$ ) were amplified from genomic DNA using previously described primers (Triplett et al. 2015; Young et al. 2008). PCR products were purified using the Qiaquick PCR Purification kit (Qiagen, Valencia, CA) according to the manufacturer's instructions but eluted in $30 \mu$ of sterile water, then directly sequenced at Genewiz (San Francisco, CA). Generated sequences were aligned, trimmed, and concatenated in MEGA7 (Kumar et al. 2016). Partial sequences totaling 3,927 bp were used for MLSA.

Phylogenetic analysis. Evolutionary history was inferred by using the maximum-likelihood method based on the equal input model (Tajima and Nei 1984). Bootstrap values were generated from 1,000 replicates. Phylogenetic trees were constructed using the neighbor-joining method (Saitou and Nei 1987). All phylogenetic analyses were performed in MEGA7 (Kumar et al. 2016). Comprehensive sequences and phylogenetic data were submitted to TreeBase under study number S20566.

Genome sequencing, assembly, and comparison. Draft genome sequences were generated for $X$. vasicola $\mathrm{pv}$. vasculorum strains NE744 (Holt County, NE) and the historic South African strain X. vasicola pv. vasculorum SAM119 (Qhobela et al. 1990) using DNA extracted as described above. Genomic libraries were prepared at Michigan State University's Research Technology Core Facility (East Lansing) using the Illumina TruSeq Nano DNA Library Preparation kit. Completed libraries were quality checked and quantified using a combination of Qubit dsDNA HS, Caliper LabChipGX HS DNA, and Kapa Illumina Library Quantification qPCR assays. Libraries were pooled and loaded on an Illumina MiSeq standard v2 flow cell; sequencing was performed in a 2-by75-bp paired-end format for NE744 and a 2-by-250-bp paired-end format for SAM119 using a v2 500 cycle MiSeq reagent cartridge. Base calling was done by Illumina Real-Time Analysis (RTA) v1.18.64 and output of RTA was demultiplexed and converted to FastQ format with Illumina Bcl2fastq v1.8.4. Genomes were assembled using SPAdes v3.9.0 (Bankevich et al.2012). QUASTwas used to assess assembly qualities (Gurevich et al. 2013). Assembled genomes were uploaded to PATRIC (Wattam et al. 2014) for preliminary annotation using a RASTtk pipeline (Brettin et al. 2015).

Disease phenotyping. Corn (hybrid 'DKC 61-88') and sorghum ('Mycogen IG588') were grown in a 1:1 mix of Promix-BX Mycorrhizae (Quakertown, PA) and Greens Grade (Profile Products, LLC, Buffalo Grove, IL), then inoculated 4 weeks after planting with eight selected bacterial strains (Table 1). Sugarcane (L-99-226) nodes were grown in a 1:1 mix of Promix-BX Mycorrhizae and sand for 2 weeks, then transplanted to $100 \%$ Promix-BX Mycorrhizae. Each bacterial strain was cultured in peptone sucrose agar (Karganilla et al. 1973) for $24 \mathrm{~h}$ at $28^{\circ} \mathrm{C}$, then suspended to $10^{8}$ CFU ml ${ }^{-1}$ in sterile, distilled water. Bacterial suspensions were infiltrated into the intercellular spaces of corn, sorghum, and sugarcane leaves on either side of the abaxial main vein with a needleless $1-\mathrm{cm}^{3}$ syringe (Reimers and Leach 1991) and by leaf clipping, as previously described (Kauffman et al. 1973). For stem inoculations, $500 \mu \mathrm{l}$ of a bacterial suspension was injected into stems using a 21-gauge needle (Vidaver 1977). Distilled water was included as a negative control in all inoculations. At least two leaves were inoculated on three to six individual plants. All inoculations with each isolatehost combination were repeated at least two times. Plants were maintained in a greenhouse $\left(27 \pm 1^{\circ} \mathrm{C}, 16\right.$-h day length, and $80 \%$ relative humidity). At 7 days postinoculation (dpi), lesions on infiltrated and stab-inoculated plants were measured; the rating scale proposed by Coutinho (1988) was applied for stab-inoculated plants.

Molecular diagnostic assay development. Draft genomes were collected from the National Center for Biotechnology Information (NCBI) Genome database for all strains listed in Table 2, with the exception of two sequenced genomes generated in this study. Unique loci that were conserved in all $X$. vasicola pv. vasculorum genomes but either not present in $X$. vasicola pv. holcicola or $X$. campestris pv. musacearum or polymorphic in these strains relative to $X$. vasicola pv. vasculorum were targeted for development of diagnostic primers. Design was done using an in-house genome alignment-based computational pipeline: UniqPrimer (L. Triplett and J. E. Leach, unpublished data, code available upon request). UniqPrimer runs a comparative analysis to identify unique loci in the included genomes that are absent in excluded genomes and then designs primers for these regions. Draft genome sequences of all publicly available $X$. vasicola pv. vasculorum and genomes generated in this study were set as "include" genomes in UniqPrimer whereas X. vasicola pv. holcicola, $X$. campestris pv. musacearum, other xanthomonads, as well as phylogenetic outliers were set as "exclude" genomes. Default settings were used in this design and yielded over 50 potential diagnostic primer sets; however, outputs are not ranked or curated. Specificity of primer targets was validated in silico by PrimerBLAST (Ye et al. 2012) against the NCBI whole-genome shotgun (wgs) database where any non- $X$. vasicola $\mathrm{pv}$. vasculorum hits were discarded. Next, a robust set of primers located across the genome were synthesized (IDT, Coralville, IA) and screened in the lab first with a small panel of DNA from positive and negative control strains. 
Primer sets that successfully amplified only positive controls were then evaluated on the remaining $X$. vasicola pv. vasculorum isolates from diverse hosts and a set of negative control isolates comprising several different Xanthomonas spp. and other genera of phytobacteria by conventional PCR, as previously described (Lang et al. 2010, 2014). Negative controls pools were also separately spiked with a positive control DNA to ensure detection. Additionally, genome comparisons revealed variation among $X$. vasicola pv. vasculorum isolates in the presence or absence of the $x o p A F$ gene that encodes the bacterial effector XopAF (Studholme et al. 2010; Wasukira et al. 2014). Primers were designed using Geneious 8.0.5 (http:// www.geneious.com/) to amplify a 362-bp fragment of xopAF by aligning $x o p A F$ sequences of five $X$. vasicola pv. vasculorum strains (NCPPB accessions 702, 890, 895, 1326, and 1381) retrieved from the GenBank wgs database. Each $25-\mu$ l reaction included $1 \mu \mathrm{l}$ of each primer at $10 \mu \mathrm{M}$ (Table 3 ), $15.7 \mu \mathrm{l}$ of water, $5 \mu \mathrm{l}$ of $5 \times$ GoTaq reaction buffer, $0.75 \mu \mathrm{l}$ of $25 \mathrm{mM} \mathrm{MgCl}_{2}, 0.5 \mu \mathrm{l}$ of $10 \mathrm{mM} \mathrm{dNTP}$, and
$0.05 \mu \mathrm{l}$ of GoTaq DNA polymerase (Promega Corp., Madison, WI). Optimized cycling conditions were an initial denaturation at $94^{\circ} \mathrm{C}$ for $3 \mathrm{~min}$; followed by 30 cycles of $94^{\circ} \mathrm{C}$ for $30 \mathrm{~s}$, annealing temperature specific to each primer (Table 3 ) for $30 \mathrm{~s}$, and $72^{\circ} \mathrm{C}$ for $1 \mathrm{~min}$; with a final elongation at $72^{\circ} \mathrm{C}$ for $10 \mathrm{~min}$.

PCR-based detection of $X$. vasicola pv. vasculorum in corn leaves. To detect the presence of $X$. vasicola $\mathrm{pv}$. vasculorum in corn leaf tissue, a small section (approximately $3 \mathrm{~cm}$ ) with a characteristic lesion was excised to include tissue beyond the lesion margin. The leaf tissue was surface disinfested in $5 \mathrm{ml}$ of fresh $10 \%$ bleach for $30 \mathrm{~s}$, with vigorous shaking. Samples were rinsed three times with 10 to $15 \mathrm{ml}$ of sterile distilled water for $30 \mathrm{~s}$ Using flamesterilized forceps, the tissue was placed in $1 \mathrm{ml}$ of sterile distilled water in a sterile $1.5-\mathrm{ml}$ microcentrifuge tube. The tissue was cut several times to promote release of bacteria with flame-sterilized scissors, then incubated at room temperature for at least $1 \mathrm{~h}$. For bacterial isolation, one loopful $(10 \mu \mathrm{l})$ of solution was spread onto

TABLE 1. Bacterial strains used in this study and confirmed specificity of diagnostic primers for Xanthomonas vasicola pv. holcicola (Xvh) and X. vasicola pv. vasculorum (Xvv)

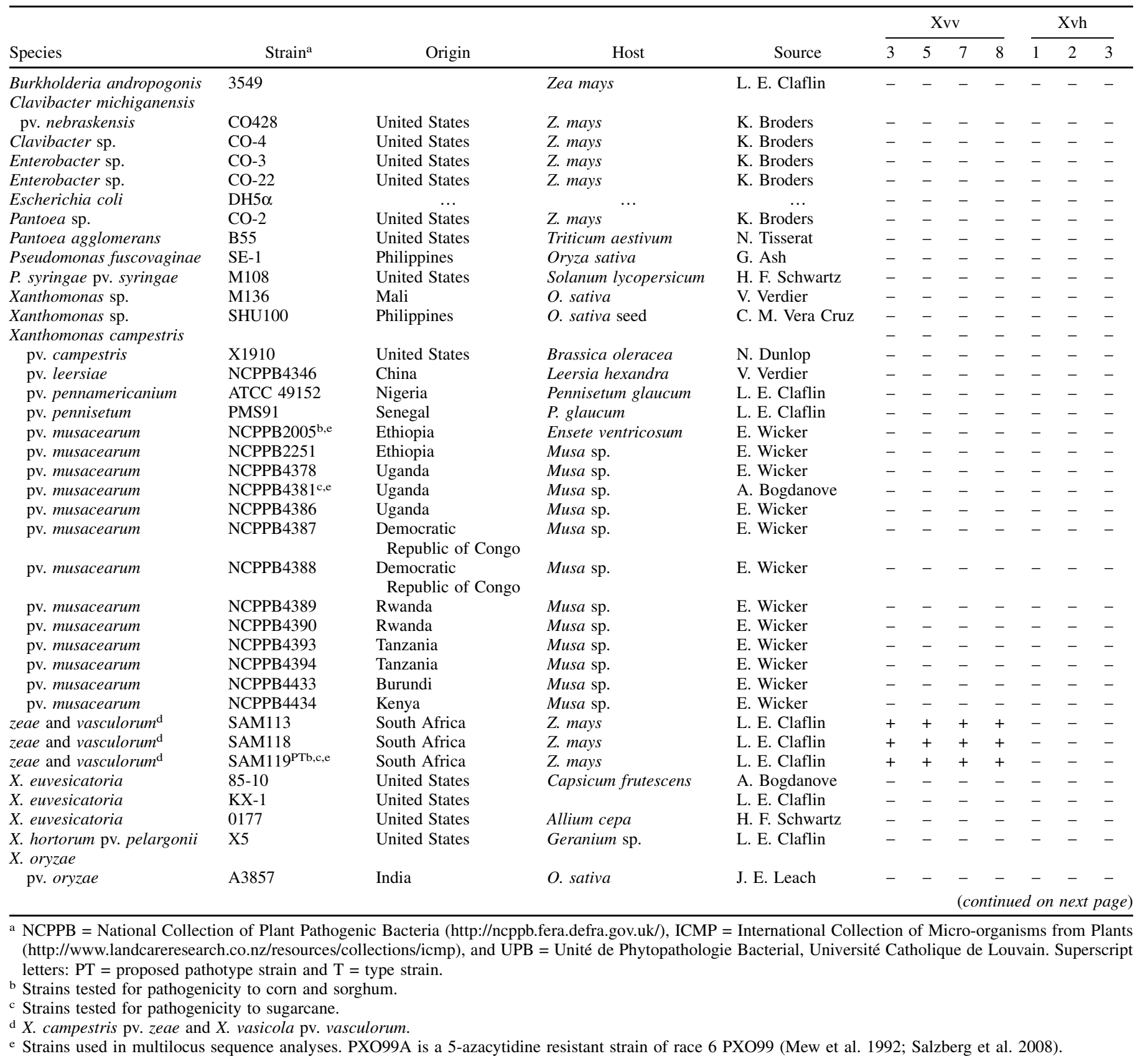


nutrient agar and incubated at $28^{\circ} \mathrm{C}$ for 2 days. Single-characteristic yellow colonies were selected and restreaked for isolated colonies on nutrient agar; then, a single colony was selected and suspended in water for use in colony PCR. Alternatively, $X$. vasicola $\mathrm{pv}$. vasculorum was directly detected using $1 \mu \mathrm{l}$ of leachate from the cut tissue as the DNA template for direct PCR.

\section{RESULTS}

MLSA. DNA gyrase B is an accepted benchmark to delineate Xanthomonas spp. (Parkinson et al. 2009, 2007). A preliminary alignment of the DNA gyrase B gene ( gyrB) of Xanthomonas strains representing over 27 different described species and Stenotrophomonas maltophilia K279a as an outgroup was used to evaluate the placement of recent isolates of $X$. vasicola $\mathrm{pv}$. vasculorum from corn in the genus Xanthomonas (Supplementary Fig. S1). Strains NE744 and NE181, isolated in 2015 from dent corn in two different counties of Nebraska (Holt and Cedar, respectively), grouped with $X$. vasicola pv. holcicola and X. vasicola pv. vasculorum from corn and sugarcane as well as $X$. campestris pv. musacearum from banana, consistent with its identification as $X$. vasicola (Korus et al. 2017).

MLSA using six different housekeeping genes (atpD, dnaK, gyrB, fusA, lepA, and rpoD) established genotypic relationships of the U.S. corn strains with other Xanthomonas spp. S. maltophilia K279A and X. albilineans GPEPC73 (causal agent of leaf scald of sugarcane) were included in the analysis as outgroups (Fig. 1). $X$. vasicola pv. vasculorum and $X$. campestris pv. musacearum group together in one clade, with $X$. vasicola pv. holcicola next in proximity (Fig. 1). The sequences for the six genes were identical for the South African strain SAM119 and all other X. vasicola pv. vasculorum strains; thus, they grouped into a single clade. Three single-nucleotide polymorphisms (SNP) were identified in the six concatenated genes between the $X$. vasicola pv. vasculorum and $X$. campestris pv. musacearum strains. Fifteen SNP differentiated

TABLE 1. (continued from preceding page)

\begin{tabular}{|c|c|c|c|c|c|c|c|c|c|c|c|}
\hline \multirow[b]{2}{*}{ Species } & \multirow[b]{2}{*}{ Strain $^{\mathrm{a}}$} & \multirow[b]{2}{*}{ Origin } & \multirow[b]{2}{*}{ Host } & \multirow[b]{2}{*}{ Source } & \multicolumn{4}{|c|}{ Xvv } & \multicolumn{3}{|c|}{ Xvh } \\
\hline & & & & & 3 & 5 & 7 & 8 & 1 & 2 & 3 \\
\hline pv. oryzae & BAI3 & Burkina Faso & O. sativa & V. Verdier & - & - & - & - & - & - & - \\
\hline pv. oryzae & R3 & Australia & O. sativa & J. E. Leach & - & - & - & - & - & - & - \\
\hline pv. oryzae & Xoo4 & Thailand & O. sativa & J. E. Leach & - & - & - & - & - & - & - \\
\hline pv. oryzae & MAI1 & Mali & O. sativa & V. Verdier & - & - & - & - & - & - & - \\
\hline pv. oryzae & NAI8 & Niger & O. sativa & V. Verdier & - & - & - & - & - & - & - \\
\hline pv. oryzae & PXO86 & Philippines & O. sativa & C. M. Vera Cruz & - & - & - & - & - & - & - \\
\hline pv. oryzae & PXO99A ${ }^{\mathrm{e}}$ & Philippines & O. sativa & J. E. Leach & - & - & - & - & - & - & - \\
\hline pv. oryzae & $\mathrm{X} 11-5 \mathrm{~A}$ & United States & O. sativa & C. Gonzalez & - & - & - & - & - & - & - \\
\hline pv. oryzae & Xoo199 & Korea & O. sativa & S. H. Choi & - & - & - & - & - & - & - \\
\hline pv. oryzicola & BLS98 & Philippines & O. sativa & C. M. Vera Cruz & - & - & - & - & - & - & - \\
\hline pv. oryzicola & BLS105 & Philippines & O. sativa & C. M. Vera Cruz & - & - & - & - & - & - & - \\
\hline pv. oryzicola & BLS256 & Philippines & O. sativa & C. M. Vera Cruz & - & - & - & - & - & - & - \\
\hline pv. oryzicola & BLS305 & Philippines & O. sativa & C. M. Vera Cruz & - & - & - & - & - & - & - \\
\hline pv. oryzicola & MAI4 & Mali & O. sativa & V. Verdier & - & - & - & - & - & - & - \\
\hline pv. oryzicola & MAI10 & Mali & O. sativa & V. Verdier & - & - & - & - & - & - & - \\
\hline \multicolumn{12}{|l|}{ X. translucens } \\
\hline pv. cerealis & NCPPB 1943 & United States & T. aestivum & L. E. Claflin & - & - & - & - & - & - & - \\
\hline pv. cerealis & NCPPB 1944 & United States & Bromus inermis & V. Verdier & - & - & - & - & - & - & - \\
\hline pv. phleipratensis & ICMP5744 & United States & Phleum pretense & L. E. Claflin & - & - & - & - & - & - & - \\
\hline pv. translucens & B76 & United States & Hordeum vulgare & N. Tisserat & - & - & - & - & - & - & - \\
\hline pv. translucens & NCPPB2389 & India & H. vulgare & C. Bragard & - & - & - & - & - & - & - \\
\hline pv. translucens & UPB787 & Paraguay & H. vulgare & C. Bragard & - & - & - & - & - & - & - \\
\hline pv. undulosa & UPB513 & Mexico & T. aestivum & C. Bragard & - & - & - & - & - & - & - \\
\hline \multicolumn{12}{|l|}{$X$. vasicola } \\
\hline pv. holcicola & 66 & Kansas & Sorghum bicolor & L. E. Claflin & - & - & - & - & + & + & + \\
\hline pv. holcicola & 86 & Kansas & S. bicolor & L. E. Claflin & - & - & - & - & + & + & + \\
\hline pv. holcicola & 93 & Kansas & S. bicolor & L. E. Claflin & - & - & - & - & + & + & + \\
\hline pv. holcicola & 107 & Lesotho & S. bicolor & L. E. Claflin & - & - & - & - & + & + & + \\
\hline pv. holcicola & 114 & Lesotho & S. bicolor & L. E. Claflin & - & - & - & - & + & + & + \\
\hline pv. holcicola & 123 & Lesotho & S. bicolor & L. E. Claflin & - & - & - & - & + & + & + \\
\hline pv. holcicola & 124 & Lesotho & S. bicolor & L. E. Claflin & - & - & - & - & + & + & + \\
\hline pv. holcicola & Mex-1 $1^{\mathrm{b}, \mathrm{c}}$ & Mexico & S. bicolor & L. E. Claflin & - & - & - & - & + & + & + \\
\hline pv. holcicola & NCPPB989e & Texas & Holcus sp. & L. E. Claflin & - & - & - & - & + & + & + \\
\hline pv. holcicola & NCPPB $1241^{\mathrm{b}, \mathrm{c}}$ & Australia & S. bicolor & L. E. Claflin & - & - & - & - & + & + & + \\
\hline pv. holcicola & NCPPB $2417^{\mathrm{Tb}, \mathrm{c}, \mathrm{e}}$ & New Zealand & S. bicolor & L. E. Claflin & - & - & - & - & + & + & + \\
\hline pv. holcicola & SAS $211^{\mathrm{c}, \mathrm{e}}$ & South Africa & S. bicolor & L. E. Claflin & - & - & - & - & + & + & + \\
\hline pv. holcicola & Z-5 & Zimbabwe & S. bicolor & L. E. Claflin & - & - & - & - & + & + & + \\
\hline pv. vasculorum & $201600017 x$ & Nebraska & Z. mays & T. Jackson-Ziems & + & + & + & + & - & - & - \\
\hline pv. vasculorum & $201600018 x$ & Nebraska & Z. mays & T. Jackson-Ziems & + & + & + & + & - & - & - \\
\hline pv. vasculorum & $201600039 x$ & Nebraska & Z. mays & T. Jackson-Ziems & + & + & + & + & - & - & - \\
\hline pv. vasculorum & $201600068 x$ & Nebraska & Z. mays & T. Jackson-Ziems & + & + & + & + & - & - & - \\
\hline pv. vasculorum & NE744 ${ }^{\mathrm{b}, \mathrm{c}, \mathrm{e}}$ & Nebraska & Z. mays & K. Korus & + & + & + & + & - & - & - \\
\hline pv. vasculorum & $\mathrm{NE} 181^{\mathrm{e}}$ & Nebraska & Z. mays & K. Korus & + & + & + & + & - & - & - \\
\hline pv. vasculorum & $\mathrm{CO}-5^{\mathrm{c}}$ & Colorado & Z. mays & K. Broders & + & + & + & + & - & - & - \\
\hline pv. vasculorum & KS444 & Kansas & Z. mays & J. Chaky & + & + & + & + & - & - & - \\
\hline pv. vasculorum & NCPPB206 & South Africa & Z. mays & L. E. Claflin & + & + & - & - & - & - & - \\
\hline pv. vasculorum & NCPPB $1326^{\mathrm{b}, \mathrm{c}, \mathrm{e}}$ & Zimbabwe & Saccharum officinarum & L. E. Claflin & + & + & + & + & - & - & - \\
\hline pv. vasculorum & NE429 & Nebraska & Z. mays & T. Jackson-Ziems & + & + & + & + & - & - & - \\
\hline pv. vasculorum & NE442 & Nebraska & Z. mays & L. Appel & + & + & + & + & - & - & - \\
\hline pv. vasculorum & UVZ $411^{\mathrm{c}}$ & South Africa & S. officinarum & R. A. Bailey & + & + & + & + & - & - & - \\
\hline pv. vasculorum & $\mathrm{ZCP} 611^{\mathrm{c}}$ & Zimbabwe & S. officinarum & P. Sinai & + & + & + & + & - & - & - \\
\hline
\end{tabular}


$X$. vasicola $\mathrm{pv}$. holcicola strains from $X$. vasicola $\mathrm{pv}$. vasculorum and $X$. campestris pv. musacearum. Curated sequences and alignments are in TreeBASE under study number S20566.

Genomics. Draft genomes of $X$. vasicola pv. vasculorum NE744 and SAM119 were assembled using SPAdes v3.9.0 (Bankevich et al. 2012), yielding 104 and 84 contigs $\geq 500$ bp $\left(\mathrm{N}_{50}\right.$ between 139,700 and 169,893), for total lengths of 4,869,712 and 4,856,397 bp for $X$. vasicola pv. vasculorum NE744 and SAM119, respectively. Assembled contigs and raw reads for $X$. vasicola pv. vasculorum NE744 and SAM119 were deposited to GenBank and the Sequence Read Archive with accession numbers MVYW00000000 and MVYX00000000. GC contents for these strains were 63.25 and $63.22 \%$, which is consistent with other members of the genus Xanthomonas.

Genome assemblies were used to calculate ANI to delineate species relative to other Xanthomonas spp. at a 95\% cut off using JSpecies v1.2.1 (Konstantinidis and Tiedje 2005; Richter and Rosselló-Móra 2009) (Table 2). The genomes of the causal agent of corn bacterial leaf streak isolated in Nebraska are $99 \%$ identical to X. vasicola pv. vasculorum from Madagascar, South Africa, and Zimbabwe, whether isolated from corn or sugarcane. The highest ANI percentage was between $X$. vasicola $\mathrm{pv}$. vasculorum NE744 and SAM119. Both genomes generated in this study were, on average, $98 \%$ similar to $X$. campestris $\mathrm{pv}$. musacearum from banana (Uganda or Ethiopia) and $X$. vasicola pv. holcicola isolated from sorghum or Holcus spp. (United States, Australia, or New Zealand), including the $X$. vasicola type strain NCPPB2417.

Evidence of type III and type IV secretion systems was found in preliminary annotations of the U.S. (NE744) and South African (SAM119) genomes (data not shown), similar to predictions from other X. vasicola pv. vasculorum genomes (Wasukira et al. 2014, 2012). A TBLASTN search for transcription activator-like (TAL) effector gene sequences using conserved features ( $\mathrm{N}$ and $\mathrm{C}$ termini) of this protein family from $X$. oryzae pv. oryzae and $X$. oryzae $\mathrm{pv}$. oryzicola did not reveal TAL effectors in the $X$. vasicola draft genomes. Thus, these strains do not appear to contain genes encoding TAL effectors. However, the highly repetitive sequence of
TAL effectors cannot be fully resolved by draft sequence alone and further investigation by DNA hybridization or long-read sequencing is necessary.

Pathogenicity. To determine pathogenicity, a panel of historical and recently collected strains (Table 1) were inoculated to corn, sorghum, and sugarcane using two previously reported assays, infiltration into leaves, or stab injection into the stems (Coutinho 1988; Coutinho et al. 2015; Goszczynska et al. 2007; Karamura et al. 2015; Qhobela and Claflin 1988; Qhobela et al. 1990). Phenotypes after stem injection across corn and sorghum were variable (Supplementary Figs. S2 and S3); therefore, we focused our analysis on results from quantitative leaf infiltration assays (Fig. 2). When introduced into corn leaves (hybrid DKC 61-88) by infiltration, $X$. vasicola pv. holcicola and $X$. vasicola $\mathrm{pv}$. vasculorum strains were all moderate to highly virulent (lesions of 5.6 to $10.6 \mathrm{~cm}$ ), with two exceptions: $X$. vasicola pv. vasculorum strains NCPPB206 (corn) and NCPPB1326 (sugarcane), which were weakly virulent (average lesion lengths $\leq 1.6 \mathrm{~cm}$ ). However, $X$. vasicola pv. vasculorum isolates caused less water soaking and shorter lesions on sorghum than on corn. Prolific bacterial exudate was observed after inoculation of either $X$. vasicola pv. vasculorum or X. vasicola pv. holcicola to corn or $X$. vasicola pv. holcicola to sorghum regardless of the inoculation technique used (Supplementary Fig. S4).

Sugarcane was inoculated by leaf infiltration only but, similar to corn and sorghum, lesion lengths were variable between plants and even on the same leaf (Supplementary Table S1). Representative phenotypes at 4 dpi with selected strains are shown in Figure 3. Strains of $X$. vasicola pv. vasculorum and $X$. vasicola $\mathrm{pv}$. holcicola produced a deep purple response in sugarcane leaves over time but $X$. vasicola pv. holcicola caused the earliest reaction, starting at 3 dpi. Regardless of original host, $X$. vasicola pv. vasculorum strains caused water soaking at $4 \mathrm{dpi}$; after $5 \mathrm{dpi}$, infiltration sites turned deep purple and all lesions continued to expand. Although not as abundant as on corn or sorghum, bacterial exudate was observed on sugarcane after inoculation by all $X$. vasicola $\mathrm{pv}$. vasculorum strains. $X$. campestris pv. musacearum was not pathogenic and caused no water soaking on sugarcane and, again, X. vasicola $\mathrm{pv}$. vasculorum NCPPB 1326 was not highly virulent.

TABLE 2. Average nucleotide identity (ANI) values calculated by whole-genome comparison using draft genomes

\begin{tabular}{|c|c|c|c|c|c|c|c|}
\hline \multirow[b]{2}{*}{ Species } & \multirow[b]{2}{*}{ Strain $^{b}$} & \multirow[b]{2}{*}{ Origin } & \multirow[b]{2}{*}{ Host } & \multirow[b]{2}{*}{ GenBank accession } & \multirow[b]{2}{*}{ Reference } & \multicolumn{2}{|c|}{ ANI (\%) with ${ }^{\mathrm{a}}$} \\
\hline & & & & & & NE744 & SAM119 \\
\hline Stenotrophomonas maltophilia & $\mathrm{K} 279 \mathrm{a}$ & $\begin{array}{l}\text { United } \\
\text { Kingdom }\end{array}$ & Homo sapiens & NC_010943 & Crossman et al. 2008 & 75.68 & 75.71 \\
\hline Xanthomonas albilineans & GPE PC73 & Guadeloupe & $\begin{array}{l}\text { Saccharum } \\
\text { officinarium }\end{array}$ & GCA_000087965.1 & Pieretti et al. 2009 & 79.17 & 79.17 \\
\hline X. axonopodis pv. vasculorum & NCPPB 900 & La Reunion & S. officinarium & GCA_000724905.2 & $\begin{array}{l}\text { Harrison and } \\
\text { Studholme } 2014\end{array}$ & 89.28 & 89.17 \\
\hline X. campestris pv. musacearum & NCPPB 4381 & Uganda & Musa sp. & ACHT 00000000 & Studholme et al. 2010 & 98.62 & 98.63 \\
\hline X. campestris pv. musacearum & NCPPB 2005 & Ethiopia & Ensete ventricosum & AKBE 01000000 & Wasukira et al. 2012 & 98.81 & 98.81 \\
\hline X. oryzae pv. oryzae & PXO99A & Philippines & Oryza sativa & NC_010717 & $\begin{array}{l}\text { Salzberg et al. 2008; } \\
\text { Booher et al. } 2015\end{array}$ & 90.96 & 90.9 \\
\hline \multicolumn{8}{|l|}{ X. vasicola } \\
\hline pv. holcicola & NCPPB 989 & United States & Holcus sp. & JSCA 01000000 & & 98.58 & 98.55 \\
\hline pv. holcicola & NCPPB 1241 & Australia & Sorghum vulgare & JSBV 01000000 & & 98.58 & 98.58 \\
\hline pv. holcicola & NCPPB 2417 & New Zealand & S. vulgare & JSBW 02000000 & & 98.61 & 98.57 \\
\hline pv. vasculorum & NCPPB 702 & Zimbabwe & S. officinarium & ACHS 00000000.1 & Studholme et al. 2010 & 99.38 & 99.38 \\
\hline pv. vasculorum & NCPPB 206 & South Africa & Zea mays & AKBM 00000000 & $\begin{array}{l}\text { Studholme et al. 2010; } \\
\text { Wasukira et al. 2012 }\end{array}$ & 99.50 & 99.47 \\
\hline pv. vasculorum & NCPPB 890 & South Africa & S. officinarium & AKBN 01000000 & Wasukira et al. 2014 & 99.53 & 99.52 \\
\hline pv. vasculorum & NCPPB 895 & Madagascar & S. officinarium & AKBO 01000000 & Wasukira et al. 2014 & 99.51 & 99.53 \\
\hline pv. vasculorum & NCPPB 1326 & Zimbabwe & S. officinarium & AKBK 01000000 & Wasukira et al. 2012 & 99.34 & 99.36 \\
\hline pv. vasculorum & NCPPB 1381 & Zimbabwe & S. officinarium & AKBL 00000000.1 & Wasukira et al. 2012 & 99.40 & 99.42 \\
\hline pv. vasculorum & NE744 & $\begin{array}{l}\text { Holt County, } \\
\text { Nebraska }\end{array}$ & Z. mays & MVYW00000000 & This study & n.a. & 99.98 \\
\hline $\begin{array}{l}X . \text { campestris pv. zeael } \\
\text { X. vasicola pv. vasculorum }\end{array}$ & SAM119 & $\begin{array}{l}\text { Klerksdorp, } \\
\text { South Africa }\end{array}$ & Z. mays & MVYX00000000 & Qhobela et al. 1990 & 99.98 & n.a. \\
\hline
\end{tabular}

${ }^{a}$ Percent ANI calculated using draft genome sequence in JSpecies V1.2.1 relative to strain NE744 or SAM119; n.a. = not applicable.

b NCPPB = National Collection of Plant Pathogenic Bacteria (http://ncppb.fera.defra.gov.uk/). 
Based on our pathogenicity tests, X. vasicola pv. vasculorum strains from either corn or sugarcane cause disease on corn, sorghum, or sugarcane, but they are usually most aggressive to the host from which they were originally isolated. The disease phenotypes caused by the U.S. corn isolate on all three hosts are most similar to those caused by $X$. vasicola pv. vasculorum from South Africa. X. vasicola pv. holcicola strains are virulent to all three hosts, but are more aggressive to sorghum than the sugarcane and corn isolates.

Diagnostics. Four primer sets (Xvv 3, Xvv5, Xvv7, and Xvv8) were generated that specifically amplify $X$. vasicola $\mathrm{pv}$. vasculorum from isolated DNA, heat-killed cells, or infected, macerated tissues, and that did not amplify any nontarget strains. Gene targets, primer sequences, and recommended annealing temperatures are listed in Table 3. In total, 17 strains positively amplified with the four sets of $X$. vasicola pv. vasculorum primers and were differentiated from the $X$. vasicola pv. holcicola, $X$. campestris pv. musacearum, and other nontarget strains by these assays. No false positives (i.e., amplification of nontarget strains) were detected. Furthermore, if the primers amplified DNA from plant exudates, if leaf tissue was intact and not exceptionally decomposed, $X$. vasicola $\mathrm{pv}$. vasculorum was isolated from the leaves ( 9 of 13 samples). $X$. vasicola pv. vasculorum NCPPB206 did not amplify with primers Xvv7 or Xvv8. Primers specific for X. vasicola pv. holcicola were also generated and tests with the same sets of target and nontarget strains revealed consistent amplification of target strains and no false positives (Tables 3 and 1). Predicted gene function of loci identified for primer design from draft genome sequences are included in Table 3 .

XopAF. The effector gene $x o p A F$ was reported in $X$. euvesicatoria, $X$. translucens pv. translucens, $X$. citri subsp. citri, and $X$. vasicola $\mathrm{pv}$. vasculorum from sugarcane but was absent in the only other strain of $X$. vasicola pv. vasculorum publicly available from corn, NCPPB206, and also absent in $X$. campestris pv. musacearum (Jalan et al. 2013; Studholme et al. 2010; Wasukira et al. 2014). To determine whether newly isolated corn strains from the United States contained this effector or close relatives, we tested for the effector gene using $x o p A F$-specific primers (Table 3). No strain of $X$. vasicola pv. vasculorum isolated from corn in the United States, no $X$. vasicola pv. holcicola or X. campestris pv. musacearum contained XopAF, whereas all sugarcane strains of $X$. vasicola pv. vasculorum did possess this gene regardless of geographic region of isolation (Fig. 4).

\section{DISCUSSION}

The causal agent of the bacterial leaf streak that recently emerged on corn in the United States was reported as X. vasicola (Korus et al.
2017). In this study, we performed phylogenetic analyses and compared genome sequences and host ranges of $X$. vasicola isolated from corn, sugarcane, and sorghum to refine the taxonomic designation of the U.S. corn isolates. We confirm that the pathogen causing bacterial streak of corn in the United States is $X$. vasicola, and propose the designation $X$. vasicola pv. vasculorum (Cobb 1894) comb. nov. Furthermore, we propose strain SAM119 (Qhobela et al. 1990) as the pathotype strain. Below, we summarize our results and rationale for these conclusions.

$X$. campestris pv. vasculorum groups A and B were initially proposed based on sodium dodecyl sulfate polyacrylamide gel electrophoresis of proteins, gas chromatography of fatty acid methyl-esters, and DNA-DNA hybridization (Vauterin et al. 1992). Vauterin et al. (1995) then proposed renaming and reclassification of the species based on DNA-DNA hybridization; this report separated

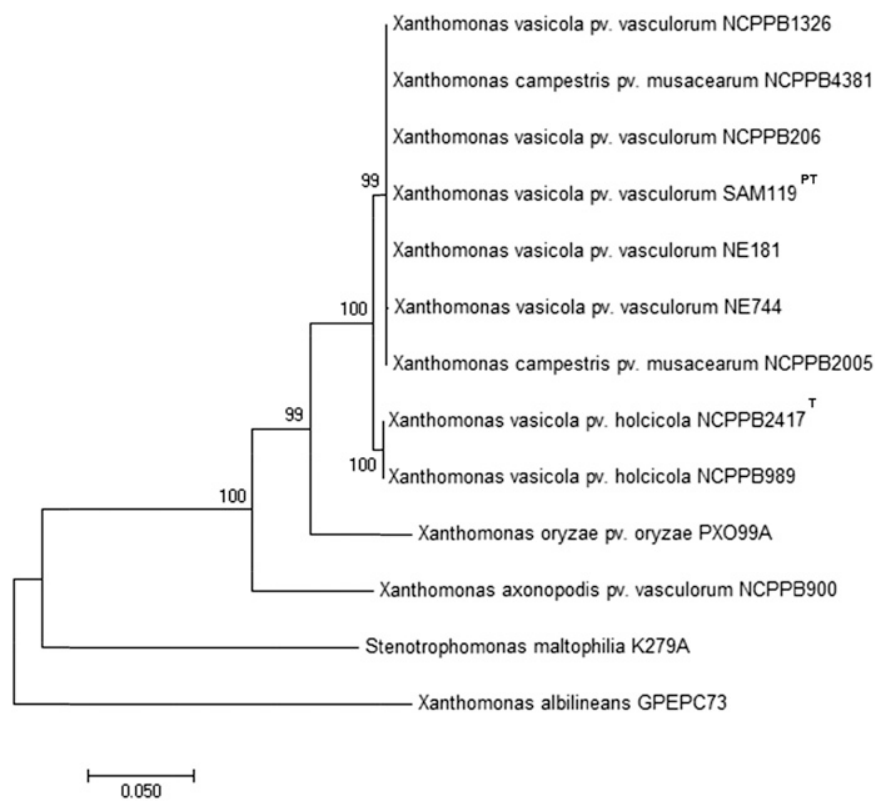

Fig. 1. Phylogeny based on partial atpD, dnaK, fusA, gyrB, lepA, and rpoD sequence alignment. The evolutionary history was inferred by using the maximum-likelihood method based on the equal input model in MEGA7 (Kumar et al. 2016). Bootstrap values generated from 1,000 replicates are shown at nodes. Branch lengths measure in the number of substitutions per site. The final dataset contained 3,967 bp. Superscript letters: $\mathrm{T}=$ type strain and $\mathrm{PT}=$ pathotype strain

TABLE 3. Primers developed with specificity to Xanthomonas vasicola pvs. vasculorum and holcicola and the effector XopAF

\begin{tabular}{|c|c|c|c|c|}
\hline Target & Name & Sequence $\left(5^{\prime}-3^{\prime}\right)$ & Product size $(\mathrm{bp})$ & Temp $\left({ }^{\circ} \mathrm{C}\right)^{\mathrm{a}}$ \\
\hline \multicolumn{5}{|l|}{ X. vasicola pv. vasculorum } \\
\hline \multirow{2}{*}{ Putative membrane protein } & Xvv3_F & CAAGCAGAGCATGGCAAAC & 207 & 55 \\
\hline & Xvv3_R & CACGTAGAACCGGTCTTTGG & & \\
\hline Putative exported protein & Xvv5_R & CGGAAGAGTTGGAAGACAGC & & \\
\hline \multirow[t]{2}{*}{ Hypothetical protein } & Xvv7_F & CTACTACGCCCAGCGACTTC & 205 & 53 \\
\hline & Xvv7_R & ACGTCGAGCCATTCTGAAAC & & \\
\hline Hypothetical protein & Xvv8_F & GGGTTATTGACGGCACTCTC & 206 & 53 \\
\hline \multirow[t]{2}{*}{ Putative acetyltransferase } & Xvh1_F & GCAGATTGTCAGCATCAGGA & 201 & 55 \\
\hline & Xvh1_R & GATCTTACGCACAGCACCAA & & \\
\hline \multirow[t]{2}{*}{ Putative membrane protein } & $\mathrm{Xvh} 2 \mathrm{~F}$ & CGAATTTTGTGTGACCAGGA & 200 & 53 \\
\hline & Xvh2_R & GAATTCACCAAATGGGCATC & & \\
\hline \multirow[t]{2}{*}{ Hypothetical protein } & Xvh3_F & ATCCCATGGGTCTGAGTCTG & 200 & 53 \\
\hline & Xvh3_R & AGTCCATTGCAGGAGTTTG & & \\
\hline XopAF & XopAF_F & CCATTGCCATTGCTAGCACC & 362 & 60 \\
\hline
\end{tabular}

a Annealing temperature. 
group A, composed of $X$. axonopodis pv. vasculorum from sugarcane, and group B, composed of $X$. vasicola pv. vasculorum from corn or sugarcane and $X$. vasicola pv. holcicola from sorghum. Our MLSA supports placement of corn strains from the United States and the previously reported South African strain SAM119 into X. vasicola group B (Fig. 1). The corn strains form a distinct clade from $X$. vasicola pv. holcicola but, interestingly, do not separate from $X$. campestris $\mathrm{pv}$. musacearum. Using comparisons of genomic similarities as measured by ANI to provide further taxonomic context (Vinatzer et al. 2017), we found that the corn and sugarcane isolates that clustered in MLSA phylogenetic trees (Fig. 1) had ANI of $>99.3 \%$ (Table 2). In addition, ANI values for $X$. vasicola $\mathrm{pv}$. holcicola and $X$. vasicola $\mathrm{pv}$. vasculorum from corn in the United States indicated approximately $98.6 \%$ genome similarity, and phylogenetic analyses showed these organisms branching into two distinct groups.

Based on MLSA, X. campestris pv. musacearum and X. vasicola pv. vasculorum were indistinguishable; however, previous wholegenome comparisons (Wasukira et al. 2012, 2014), the ANI values, and the diagnostic primers in this study (Tables 2 and 3) did

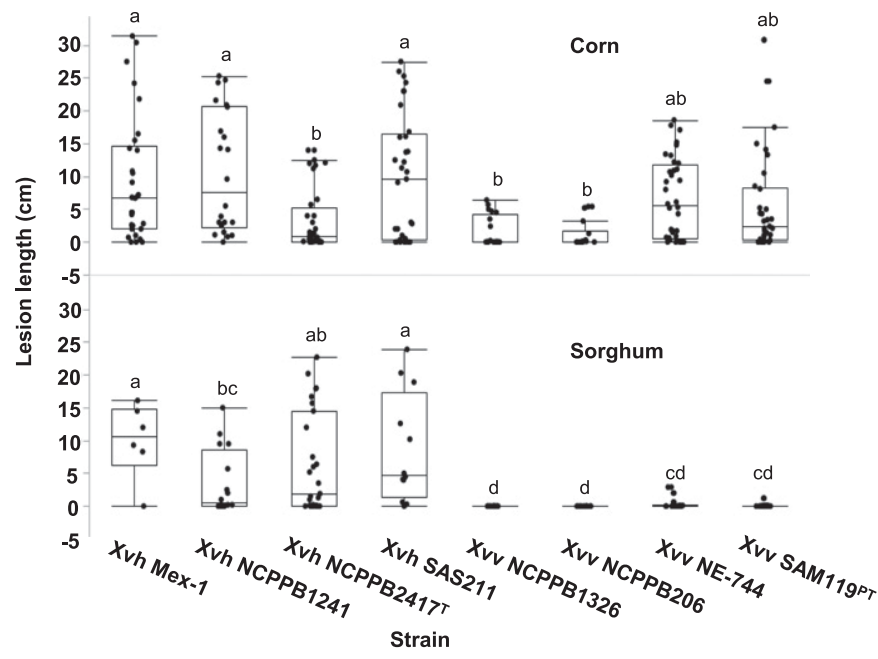

Fig. 2. Disease caused by Xanthomonas vasicola pv. vasculorum (Xvv) and X. vasicola pv. holcicola (Xvh) on corn (hybrid DKC 61-88) and sorghum (Mycogen IG588). Leaves of 4-week-old plants were infiltrated with each

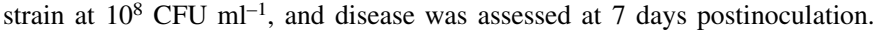
Lesion lengths indicate expansion beyond the infiltration site. The entire experiment was replicated four times and combined data from all replications is shown here. Letters designate significance at $P<0.0001$. Superscript letters: $\mathrm{T}=$ type strain and $\mathrm{PT}=$ pathotype strain. differentiate the two pathovars. Because MLSA compares only variation in housekeeping genes while ANI detects variation across the entire genome sequence, differences in predicted relationships might be expected. Therefore, host range studies are necessary to tease apart this complex. We note that neither pathogenicity of $X$. vasicola pv. vasculorum to banana nor $X$. campestris pv. musacearum to corn were assessed in this study. However, in previous studies, $X$. vasicola $\mathrm{pv}$. vasculorum from corn or sugarcane were not pathogenic to banana, and $X$. campestris pv. musacearum did not cause symptoms on corn (Aritua et al. 2008; Karamura et al. 2015). The African strain of $X$. campestris pv. musacearum (NCBBP4381) is not pathogenic to sugarcane.

Ideally, a combination of MLSA, comparison of whole-genome sequence, and ecology are integrated to define a prokaryotic species (Gevers et al. 2005; Whitman 2015). For plant-pathogenic bacteria, pathovars are distinguished based on differences in host range, although differences in symptomology on the same plant species can also warrant separate pathovar designations (Jacques et al. 2016; Young et al. 2001). Previous reports showed that corn $X$. vasicola pv. vasculorum isolates were pathogenic to corn when reintroduced but they did not cause disease on sorghum or sugarcane (Coutinho and Wallis 1991; Qhobela et al. 1990). These authors also indicated that $X$. vasicola pv. holcicola strains were pathogenic to both corn and sorghum, while a sugarcane isolate of $X$. vasicola pv. vasculorum caused disease on all three hosts. However, our results and those from other pathogenicity studies (Karamura et al. 2015), which compare some of the same isolates,

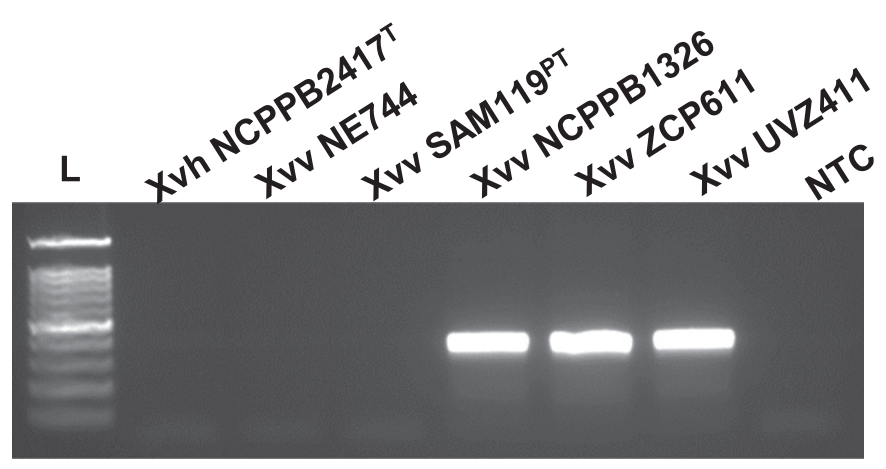

Fig. 4. Targeted amplification of xopAF in Xanthomonas vasicola pv. vasculorum (Xvv) and X. vasicola pv. holcicola (Xvh). Lane L $=100$-bp DNA ladder (GoldBio, St. Louis) and NTC $=$ no template control. Superscript letters: $\mathrm{T}=$ type strain and $\mathrm{PT}=$ pathotype strain

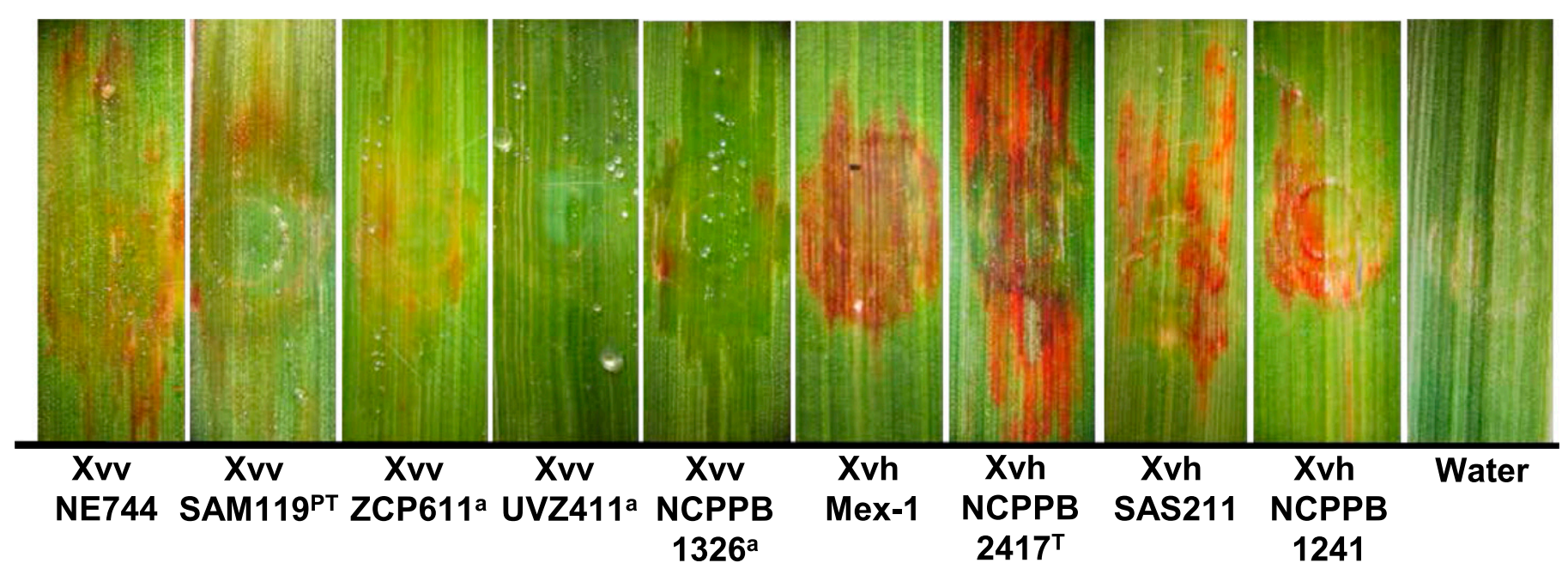

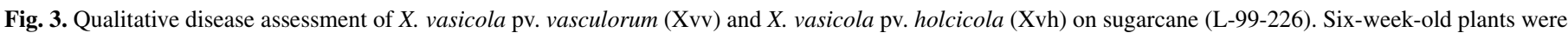

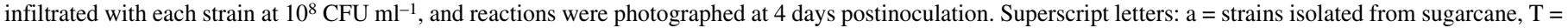
type strain, and PT = pathotype strain. 
conflicted with these results, possibly due to the use of different cultivars or experimental conditions. In our studies using established protocols, $X$. vasicola pv. vasculorum strain NE744 from corn in Nebraska was pathogenic to corn, sorghum, and sugarcane, and the symptoms (water-soaking with spreading lesions) were most similar to those caused by corn and sugarcane isolates of $X$. vasicola $\mathrm{pv}$. vasculorum from other countries. Based on our pathogenicity tests, we recommend that the U.S. and South African corn strains be included in $X$. vasicola pv. vasculorum.

$X$. vasicola pv. holcicola strains were also pathogenic to all three hosts but were more aggressive to sorghum than the corn and sugarcane isolates. We note that, when bacterial leaf streak was first observed in corn in the United States, it was thought to be caused by $X$. vasicola pv. holcicola because, in early literature based on greenhouse inoculations, $X$. vasicola pv. holcicola caused symptoms on corn (Bradbury 1986; Qhobela and Claflin 1988). However, to date, $X$. vasicola pv. holcicola has never been associated with bacterial leaf streak symptoms on corn in the field. The lack of evidence for occurrence of this pathovar on corn in the field as well as the genomic differences between the two pathovars support the current separate pathovar designation for these members of $X$. vasicola. Further phenotyping with more strains, more hosts, and different host varieties would improve resolution of the pathovar designation.

Both the sugarcane isolates of $X$. axonopodis pv. vasculorum and $X$. vasicola $\mathrm{pv}$. vasculorum are reported to cause gumming disease of sugarcane (Bradbury 1986; Dookun et al. 2000; Vauterin et al. 1995), creating confusion for pathologists. Unfortunately, little information is available on the etiology of sugarcane gumming disease, and resolution of this issue will require comparisons of host range and symptomology that include both species in optimized disease assays. A plausible hypothesis is that $X$. axonopodis $p v$. vasculorum is a vascular pathogen and causal agent of gumming disease whereas $X$. vasicola $\mathrm{pv}$. vasculorum is a nonvascular and causal agent of leaf streak.

The emergence of corn bacterial leaf streak and its spread throughout the midwestern United States created an urgent need for diagnostic tools that could be used to accurately identify the causal agent and to track its distribution. By comparing the draft genomes generated as part of this study with the large number of Xanthomonas genomes now available, we identified unique regions and used these to develop sets of diagnostic primers that distinguish $X$. vasicola $\mathrm{pv}$. vasculorum (four primer pairs) from $X$. vasicola $\mathrm{pv}$. holcicola (three primer pairs) and from other bacteria. The primers Xvv3, Xvv5, Xvh2, and Xvh3 have been tested in our labs and in collaboration with colleagues in Iowa (C. Block, A. Robertson, and G. Munkvold, Iowa State University) and Kansas (D. Jardine, Kansas State University). The primers are currently being used for disease diagnosis and for epidemiological surveys across the United States in private, public and federal institutions, including the United States Department of Agriculture (USDA) Animal and Plant Health Inspection Service (APHIS) Plant Protection and Quarantine (PPQ). Future integration of multiple loci variable number of tandem repeat analysis to specifically type populations of the $X$. vasicola complex from corn and sorghum in the United States would be valuable for epidemiological surveillance and could also help determine geographic lineages of these organisms (Poulin et al. 2015; Pruvost et al. 2014; Zhao et al. 2012).

Consistent with previous reports, of the $X$. vasicola pv. vasculorum bacteria only those from sugarcane contain the gene $x o p A F$, an effector that may contribute to host range and symptomology (Studholme et al. 2010; Wasukira et al. 2014). No evidence of TAL effectors was found in the draft genomes of $X$. vasicola pv. vasculorum strains NE744 and SAM119 but Harrison and Studholme (2014) did predict their presence in $X$. axonopodis pv. vasculorum NCPPB900. TAL effectors are found in diverse Xanthomonas spp. but are not present in all (Jacques et al. 2016). In many systems, these proteins contribute to pathogenicity. Given the absence of $x o p A F$ and genes for TAL effectors in the corn $X$. vasicola pv. vasculorum, these organisms must rely on a distinct set of effectors for virulence.

In the phylogenetic tree, the most closely related Xanthomonas spp. to $X$. vasicola is $X$. oryzae, which includes two pathovars, oryzae and oryzicola, causal agents of bacterial blight and bacterial leaf streak of rice, respectively. An interesting possibility is that these xanthomonads diverged from an ancestral group adapted to monocots. Rice and sugarcane are grown in proximity to one another in some tropical areas, which may have historically fostered evolution of these distinct groups. Although X. vasicola pv. vasculorum was previously thought to only infect monocots, including palms, it was recently identified on Eucalyptus in association with Pantoea ananatis (Coutinho et al. 2015). An outbreak of brown stalk rot on corn caused by $P$. ananatis was also reported in South Africa in 2004 (Goszczynska et al. 2007). Intriguingly, we frequently isolated $P$. ananatis from corn samples in the United States that exhibited bacterial leaf streak symptoms; however, when these $P$. ananatis were inoculated to corn, they did not cause disease (J. M. Lang, unpublished results). It is unknown whether a synergistic relationship exists between $X$. vasicola pv. vasculorum and $P$. ananatis and, if so, whether this interaction is related to the emergence of bacterial leaf streak in the United States.

The origin of the U.S. corn bacterial leaf streak pathogen is unknown. Based on ANI values, X. vasicola pv. vasculorum strain NE744 is highly similar to strain SAM119 (99.9\%) that was isolated from corn in South Africa over 20 years ago (Qhobela et al. 1990). Although it is tempting to speculate that $X$. vasicola $\mathrm{pv}$. vasculorum was introduced via international germplasm movement, given its distribution in at least seven states, pinpointing if, when, or how it was introduced would be difficult.

It is not known whether $X$. vasicola pv. vasculorum is seed transmitted, or how it is moved within and across fields. Because the disease has been confirmed on various hybrids of popcorn, seed, dent, and sweet corn (T. A. Jackson-Ziems and K. Broders, personal communication), it is unlikely that the rapid spread is due to widespread planting of one or a few susceptible varieties. The disease occurs in both irrigated and nonirrigated areas and in a variety of corn production systems, including various tillage and crop rotation regimes (T. A. Jackson-Ziems and K. Broders, personal communication). A deeper examination of the $X$. vasicola pv. vasculorum genomes from geographically diverse locations and hosts as well as epidemiological investigations are important to understanding how and why this recent epidemic in the United States has occurred.

In conclusion, the phylogenetic analyses, genome comparisons, and pathogenicity studies reported here support classification of the U.S. corn bacterial leaf streak pathogen as X. vasicola pv. vasculorum (Cobb 1894) comb. nov. (Korus et al. 2017). This classification is consistent with previous groupings of the South African corn isolates as $X$. vasicola pv. vasculorum (Aritua et al. 2008; Rademaker et al. 2005; Studholme et al. 2010; Vauterin et al. 1995; Wasukira et al. 2014). We propose a new pathotype strain, $X$. vasicola pv. vasculorum SAM119, based on historical precedence and the availability of genome sequence data (Qhobela et al. 1990; Whitman 2015). SAM119 has 99\% genomic identity with recent isolates from the United States and unlike NCPPB206, the oldest publicly available strain from corn (1949), SAM119 remains highly virulent on corn.

\section{ACKNOWLEDGMENTS}

This work was funded by USDA-APHIS-PPQ 16-8130-0714-CA and the Colorado State University Agricultural Experiment Station. We thank M. Stenglein, C. Wilusz, and their CM581 class for library preparation and sequencing of the NE744 genome; J. Hoy for providing sugarcane materials and propagation guidance; L. Triplett for providing UniqPrimer script and gyrB sequences; E. Wicker for providing $X$. campestris pv. musacearum DNA; F. White and J. Chaky for providing strains; T. Aubol for plant 
production support; G. Broders for technical advice; C. Bull, D. Studholme, and C. Hollingsworth for informative discussions; and M. Stulberg for reviewing the manuscript.

\section{LITERATURE CITED}

Adriko, J., Aritua, V., Mortensen, C. N., Tushemereirwe, W. K., Kubiriba, J., and Lund, O. S. 2012. Multiplex PCR for specific and robust detection of Xanthomonas campestris pv. musacearum in pure culture and infected plant material. Plant Pathol. 61:489-497.

Almeida, N. F., Yan, S., Cai, R., Clarke, C. R., Morris, C. E., Schaad, N. W., Schuenzel, E. L., Lacy, G. H., Sun, X., Jones, J. B., Castillo, J. A., Bull, C. T., Leman, S., Guttman, D. S., Setubal, J. C., and Vinatzer, B. A. 2010. PAMDB, a multilocus sequence typing and analysis database and website for plant-associated microbes. Phytopathology 100:208-15.

Aritua, V., Parkinson, N., Thwaites, R., Heeney, J. V., Jones, D. R., Tushemereirwe, W., Crozier, J., Reeder, R., Stead, D. E., and Smith, J. 2008. Characterization of the Xanthomonas sp. causing wilt of enset and banana and its proposed reclassification as a strain of $X$. vasicola. Plant Pathol. 57:170-177.

Ash, G. J., Lang, J. M., Triplett, L. R., Stodart, B. J., Verdier, V., Cruz, C. V., Rott, P., and Leach, J. E. 2014. Development of a genomics-based LAMP (loop-mediated isothermal amplification) assay for detection of Pseudomonas fuscovaginae from rice. Plant Dis. 98:909-915.

Bankevich, A., Nurk, S., Antipov, D., Gurevich, A. A., Dvorkin, M., Kulikov, A. S., Lesin, V. M., Nikolenko, S. I., Phan, S., Prjibelski, A. D., Pyshkin, A. V., Sirotkin, A. V., Vyahhi, N., Tesler, G., Alekseyev, M. A., and Pevzner, P. A. 2012. SPAdes: A new genome assembly algorithm and its applications to single-cell sequencing. J. Comput. Biol. 19:455-477.

Booher, N. J., Carpenter, S. C. D., Sebra, R. P., Wang, L., Salzberg, S. L., Leach, J. E., and Bogdanove, A. J. 2015. Single molecule real-time sequencing of Xanthomonas oryzae genomes reveals a dynamic structure and complex TAL (transcription activator-like) effector gene relationships. Microbiol. Genomics 1(4).

Bradbury, J. F. 1986. Guide to Plant Pathogenic Bacteria. CAB International, Farnham Royal, United Kingdom.

Brettin, T., Davis, J. J., Disz, T., Edwards, R. A., Gerdes, S., Olsen, G. J., Olson, R., Overbeek, R., Parrello, B., Pusch, G. D., Shukla, M., Thomason, J. A., III, Stevens, R., Vonstein, V., Wattam, A. R., and Xia, F. 2015. RASTtk: A modular and extensible implementation of the RAST algorithm for building custom annotation pipelines and annotating batches of genomes. Sci. Rep. 5: Article 8365.

Bull, C. T., De Boer, S. H., Denny, T. P., Firrao, G., Saux, M. F.-L., Saddler, G. S., Scortichini, M. Stead, D. E., and Takikawa, Y. 2008. Demystifying the nomenclature of bacterial plant pathogens. J. Plant Pathol. 90:403-417.

Bull, C. T., and Koike, S. T. 2015. Practical benefits of knowing the enemy: Modern molecular tools for diagnosing the etiology of bacterial diseases and understanding the taxonomy and diversity of plant-pathogenic bacteria. Annu. Rev. Phytopathol. 53:157-180.

Cobb, N. A. 1894. Plant diseases and their remedies. Diseases of the sugarcane. Agric. Gaz. N. S. W. 4:777-798.

Coutingo, T. A., and Wallis, F. M. 1991. Bacterial streak disease of maize (Zea mays L.) in South Africa. J. Phytopathol. 133:112.

Coutinho, T. 1988. Bacterial leaf streak of maize: A study on host specificity and cultivar susceptibility. Thesis, University of Natal, Pietermaritzburg, South Africa.

Coutinho, T. A., van der Westhuizen, L., Roux, J., McFarlane, S. A., and Venter, S. N. 2015. Significant host jump of Xanthomonas vasicola from sugarcane to a Eucalyptus grandis clone in South Africa. Plant Pathol. 64:576-581.

Crossman, L. C., Gould, V. C., Dow, J. M., Vernikos, G. S., Okazaki, A., Sebaihia, M., Saunders, D., Arrowsmith, C., Carver, T., Peters, N., Adlem, E., Kerhornou, A., Lord, A., Murphy, L., Seeger, K., Squares, R., Rutter, S., Quail, M. A., Rajandream, M.-A., Harris, D., Churcher, C., Bentley, S. D., Parkhill, J., Thomson, N. R., and Avison, M. B. 2008. The complete genome, comparative and functional analysis of Stenotrophomonas maltophilia reveals an organism heavily shielded by drug resistance determinants. Genome Biol. 9:R74.

Dookun, A., Stead, D. E., and Autrey, L. J.-C. 2000. Variation among strains of Xanthomonas campestris pv. vasculorum from Mauritius and other countries based on fatty acid analysis. Syst. Appl. Microbiol. 23:148-155.

Dyer, R. A. 1949. Botanical surveys and control of plant diseases. Farming in South Africa. Annu. Rep. Dep. Agric. S. Afr. 275:119-121.

Gevers, D., Cohan, F. M., Lawrence, J. G., Spratt, B. G., Coenye, T., Feil, E. J., Stackebrandt, E., Van de Peer, Y., Vandamme, P., Thompson, F. L., and Swings, J. 2005. Opinion: Re-evaluating prokaryotic species. Nat. Rev. Microbiol. 3:733-739.
Goszczynska, T., Botha, W. J., Venter, S. N., and Coutinho, T. A. 2007. Isolation and identification of the causal agent of brown stalk rot, a new disease of maize in South Africa. Plant Dis. 91:711-718.

Gurevich, A., Saveliev, V., Vyahhi, N., and Tesler, G. 2013. QUAST: Quality assessment tool for genome assemblies. Bioinformatics 29:1072-1075.

Harrison, J., and Studholme, D. J. 2014. Draft genome sequence of Xanthomonas axonopodis pathovar vasculorum NCPPB 900. FEMS Microbiol. Lett. 360:113-116.

Jacques, M.-A., Arlat, M., Boulanger, A., Boureau, T., Carrère, S., Cesbron, S., Chen, N. W. G., Cociancich, S., Darrasse, A., Denancé, N., Fischer-Le Saux, M., Gagnevin, L., Koebnik, R., Lauber, E., Noël, L. D., Pieretti, I., Portier, P., Pruvost, O., Rieux, A., Robène, I., Royer, M., Szurek, B., Verdier, V., and Vernière, C. 2016. Using ecology, physiology, and genomics to understand host specificity in Xanthomonas. Annu. Rev. Phytopathol. 54:163-187.

Jalan, N., Kumar, D., Andrade, M. O., Yu, F., Jones, J. B., Graham, J. H., White, F. F., Setubal, J. C., and Wang, N. 2013. Comparative genomic and transcriptome analyses of pathotypes of Xanthomonas citri subsp. citri provide insights into mechanisms of bacterial virulence and host range. BMC Genomics 14:551.

Karamura, G., Smith, J., Studholme, D., Kubiriba, J., and Karamura, E. 2015. Comparative pathogenicity studies of the Xanthomonas vasicola species on maize, sugarcane and banana. Afr. J. Plant Sci. 9:385-400.

Karganilla, A., Paris-Natural, M., and Ou, S. H. 1973. A comparative study of culture media for Xanthomonas oryzae. Philipp. Agric. 57:141-152.

Kauffman, H. E., Reddy, A. P. K., Hsieh, S. P. Y., and Merca, S. D. 1973. Improved technique for evaluating resistance of rice varieties to Xanthomonas oryzae. Plant Dis. Rep. 57:537-541.

Konstantinidis, K. T., and Tiedje, J. M. 2005. Genomic insights that advance the species definition for prokaryotes. Proc. Natl. Acad. Sci. USA 102: 2567-2572.

Korus, K., Lang, J. M., Adesemoye, A. O., Block, C. C., Pal, N., Leach, J. E., and Jackson-Ziems, T. A. 2017. First report of Xanthomonas vasicola causing bacterial leaf streak on corn in the United States. Plant Dis. 101: 1030.

Kumar, S., Stecher, G., and Tamura, K. 2016. MEGA7: Molecular Evolutionary Genetics Analysis version 7.0 for bigger datasets. Mol. Biol. Evol. 33:1870-1874.

Lang, J. M., Hamilton, J. P., Diaz, M. G. Q., Van Sluys, M. A., Burgos, M. R. G., Vera Cruz, C. M., Buell, C. R., Tisserat, N. A., and Leach, J. E. 2010. Genomics-based diagnostic marker development for Xanthomonas oryzae pv. oryzae and X. oryzae pv. oryzicola. Plant Dis. 94:311-319.

Lang, J. M., Langlois, P., Nguyen, M. H. R., Triplett, L. R., Purdie, L., Holton, T. A., Djikeng, A., Vera Cruz, C. M., Verdier, V., and Leach, J. E. 2014. Sensitive detection of Xanthomonas oryzae pathovars oryzae and oryzicola by loop-mediated isothermal amplification. Appl. Environ. Microbiol. 80: 4519-4530.

Langlois, P. A., Snelling, J., Hamilton, J., Bragard, C., Koebnik, R., Verdier, V., Triplett, L. R., Blom, J., Tisserat, N. A., and Leach, J. E. 2017. Characterization of the Xanthomonas translucens complex using draft genomes, comparative genomics, phylogenetic analysis, and diagnostic LAMP assays. Phytopathology 107:519-527.

Lapage, S., Sneath, P., Lessel, E., Skerman, V., Seeliger, H., and Clark, W. 1992. International Code of Nomenclature of Bacteria. ASM Press, Washington, D.C.

Lewis Ivey, M. L., Tusiime, G., and Miller, S. A. 2010. A polymerase chain reaction assay for the detection of Xanthomonas campestris pv. musacearum in banana. Plant Dis. 94:109-114.

Mew, T. W., Vera, C. M. C., and Medalla, E. S. 1992. Changes in race frequency of Xanthomonas oryzae pv. oryzae in response to rice cultivars planted in the Philippines. Plant Dis. 76:1029-1032.

Parkinson, N., Aritua, V., Heeney, J., Cowie, C., Bew, J., and Stead, D. 2007. Phylogenetic analysis of Xanthomonas species by comparison of partial gyrase B gene sequences. Int. J. Syst. Evol. Microbiol. 57:2881-2887.

Parkinson, N., Cowie, C., Heeney, J., and Stead, D. 2009. Phylogenetic structure of Xanthomonas determined by comparison of $\operatorname{gyrB}$ sequences. Int. J. Syst. Evol. Microbiol. 59:264-274.

Pieretti, I., Royer, M., Barbe, V., Carrere, S., Koebnik, R., Cociancich, S., Couloux, A., Darrasse, A., Gouzy, J., Jacques, M.-A., Lauber, E., Manceau, C., Mangenot, S., Poussier, S., Segurens, B., Szurek, B., Verdier, V., Ariat, M., and Rott, P. 2009. The complete genome sequence of Xanthomonas albilineans provides new insights into the reductive genome evolution of the xylem-limited Xanthomonadaceae. BMC Genomics 10:616.

Poulin, L., Grygiel, P., Magne, M., Gagnevin, L., Rodriguez-R, L. M., Forero Serna, N., Zhao, S., El Rafii, M., Dao, S., Tekete, C., Wonni, I., Koita, O., Pruvost, O., Verdier, V., Vernière, C., and Koebnik, R. 2015. New multilocus variable-number tandem-repeat analysis tool for surveillance and local epidemiology of bacterial leaf blight and bacterial leaf streak of rice caused by Xanthomonas oryzae. Appl. Environ. Microbiol. 81:688-698. 
Pruvost, O., Magne, M., Boyer, K., Leduc, A., Tourterel, C., Drevet, C., Ravigné, V., Gagnevin, L., Guérin, F., Chiroleu, F., Koebnik, R., Verdier, V., and Vernière, C. 2014. A MLVA genotyping scheme for global surveillance of the citrus pathogen Xanthomonas citri pv. citri suggests a worldwide geographical expansion of a single genetic lineage. PLoS One 9:e98129.

Qhobela, M., and Claflin, L. E. 1988. Characterization of Xanthomonas campestris pv. pennamericanum $\mathrm{pV}$. nov., causal agent bacterial leaf streak of pearl millet. Int. J. Syst. Evol. Bacteriol. 38:362-366.

Qhobela, M., and Claflin, L. E. 1992. Eastern and southern African strains of Xanthomonas campestris pv. vasculorum are distinguishable by restriction fragment length polymorphism of DNA and polyacrylamide gel electrophoresis of membrane proteins. Plant Pathol. 41:113-121.

Qhobela, M., Claflin, L. E., and Nowell, D. C. 1990. Evidence that Xanthomonas campestris pv. zeae can be distinguished from other pathovars capable of infecting maize by restriction fragment length polymorphism of genomic DNA. Can. J. Plant Pathol. 12:183-186.

Rademaker, J. L. W., Louws, F. J., Schultz, M. H., Rossbach, U., Vauterin, L., Swings, J., and de Bruijn, F. J. 2005. A comprehensive species to strain taxonomic framework for Xanthomonas. Phytopathology 95:1098-1111.

Reimers, P. J., and Leach, J. E. 1991. Race-specific resistance to Xanthomonas oryzae pv. oryzae conferred by bacterial blight resistance gene $\mathrm{Xa}-10$ in rice Oryza sativa involves accumulation of a lignin-like substance in host tissues. Physiol. Mol. Plant Pathol. 38:39-55.

Richter, M., and Rosselló-Móra, R. 2009. Shifting the genomic gold standard for the prokaryotic species definition. Proc. Natl. Acad. Sci. USA 106: 19126-19131.

Saitou, N., and Nei, M. 1987. The neighboring-joining method: A new method for reconstructing phylogenetic trees. Mol. Biol. Evol. 4:406-425.

Salzberg, S. L., Sommer, D. D., Schatz, M. C., Phillippy, A. M., Rabinowicz, P. D., Tsuge, S., Furutani, A., Ochiai, H., Delcher, A. L., Kelley, D., Madupu, R., Pulu, D., Radune, D., Shumway, M., Trapnell, C., Aparna, G., Jha, G., Pandey, A., Patil, P. B., Ishihara, H., Meyer, D. F., Szurek, B., Verdier, V., Koebnik, R., Dow, J. M., Ryan, R. P., Hirata, H., Tsuyumu, S., Lee, S. W., Ronald, P. C., Sonti, R. V., Van Sluys, M.-A., Leach, J. E., White, F. F., and Bogdanove, A. J. 2008. Genome sequence and rapid evolution of the rice pathogen Xanthomonas oryzae pv. oryzae PXO99A. BMC Genomics 9:204.

Studholme, D. J., Kemen, E., MacLean, D., Schornack, S., Aritua, V., Thwaites, R., Grant, M., Smith, J., and Jones, J. D. G. 2010. Genome-wide sequencing data reveals virulence factors implicated in banana Xanthomonas wilt. FEMS Microbiol. Lett. 310:182-192.

Tajima, F., and Nei, M. 1984. Estimation of evolutionary distance between nucleotide sequences. Mol. Biol. Evol. 1:269-285.

Triplett, L. R., Verdier, V., Campillo, T., Van Malderghem, C., Cleenwerck, I., Maes, M., Deblais, L., Corral, R., Koita, O., Cottyn, B., and Leach, J. E. 2015. Characterization of a novel clade of Xanthomonas isolated from rice leaves in Mali and proposal of Xanthomonas maliensis sp. nov. Antonie Leeuwenhoek 107:869-881.

Vauterin, L., Hoste, B., Kersters, K., and Swings, J. 1995. Reclassification of Xanthomonas. Int. J. Syst. Bacteriol. 45:472-489.
Vauterin, L., Yang, P., Hoste, B., Swings, J., and Kersters, K. 1992. Taxonomy of xanthomonads from cereals and grasses based on SDS-PAGE of proteins, fatty acid analysis and DNA hybridization. J. Gen. Microbiol. 138: 1467-1477.

Verdier, V., Triplett, L. R., Corral, R., and Leach, J. E. 2011. Genome-enabled primer design to distinguish geographic origin of Xanthomonas oryzae pvs. oryzicola and oryzae. (Abstr.) Phytopathology 101:S183.

Vidaver, A. K. 1977. Maintenance of viability and virulence of Corynebacterium nebraskense. Phytopathology 67:825-827.

Vinatzer, B. A., Weisberg, A. J., Monteil, C. L., Elmarakeby, H. A., Sheppard, S. K., and Heath, L. S. 2017. A proposal for a genome similarity-based taxonomy for plant-pathogenic bacteria that is sufficiently precise to reflect phylogeny, host range, and outbreak affiliation applied to Pseudomonas syringae sensu lato as a proof of concept. Phytopathology 107:18-28.

Wasukira, A., Coulter, M., Al-Sowayeh, N., Thwaites, R., Paszkiewicz, K., Kubiriba, J., Smith, J., Grant, M., and Studholme, D. J. 2014. Genome sequencing of Xanthomonas vasicola pv. vasculorum reveals variation in plasmids and genes encoding lipopolysaccharide synthesis, type-IV pilus and type-III secretion effectors. Pathogens 3:211-237.

Wasukira, A., Tayebwa, J., Thwaites, R., Paszkiewicz, K., Aritua, V., Kubiriba, J., Smith, J., Grant, M., and Studholme, D. J. 2012. Genome-wide sequencing reveals two major sub-lineages in the genetically monomorphic pathogen Xanthomonas campestris pathovar musacearum. Genes 3:361-377.

Wattam, A. R., Abraham, D., Dalay, O., Disz, T. L., Driscoll, T., Gabbard, J. L., Gillespie, J. J., Gough, R., Hix, D., Kenyon, R., Machi, D., Mao, C., Nordberg, E. K., Olson, R., Overbeek, R., Pusch, G. D., Shukla, M., Schulman, J., Stevens, R. L., Sullivan, D. E., Vonstein, V., Warren, A., Will, R., Wilson, M. J. C., Yoo, H. S., Zhang, C., Zhang, Y., and Sobral, B. W. 2014. PATRIC, the bacterial bioinformatics database and analysis resource. Nucleic Acids Res. 42:D581-D591.

Whitman, W. B. 2015. Genome sequences as the type material for taxonomic descriptions of prokaryotes. Syst. Appl. Microbiol. 38:217-222.

Ye, J., Coulouris, G., Zaretskaya, I., Cutcutache, I., Rozen, S., and Madden, T. L. 2012. Primer-BLAST: A tool to design target-specific primers for polymerase chain reaction. BMC Bioinf. 13:134.

Young, J. M., Bull, C. T., De Boer, S. H., Firrao, G., Gardan, L., Saddler, G. E., Stead, D. E., and Takikawa, Y. 2001. International Standards for Naming Pathovars of Phytopathogenic Bacteria. Online publication. http://www. isppweb.org/about_tppb_naming.asp

Young, J. M., Dye, D. W., Bradbury, J. F., Panagopoulos, C. G., and Robbs, C. F. 1978. A proposed nomenclature and classification for plant pathogenic bacteria. N. Z. J. Agric. Res. 21:153-177.

Young, J. M., Park, D. C., Shearman, H. M., and Fargier, E. 2008. A multilocus sequence analysis of the genus Xanthomonas. Syst. Appl. Microbiol. 31:366-377.

Zhao, S., Poulin, L., Rodriguez, R. L., Serna, N. F., Liu, S. Y., Wonni, I. 2012. Development of a variable number of tandem repeats typing scheme for the bacterial rice pathogen Xanthomonas oryzae pv. oryzicola. Phytopathology 102:948-956. 